ACTA AGROBOTANICA

Vol. 66 (3), 2013: 23-30

Original Research Paper

DOI: 10.5586/aa.2013.034

\title{
THE SIZE STRUCTURE OF RAMETS IN Dianthus superbus L. IN MOSAIC MEADOW VEGETATION
}

\author{
Kinga Kostrakiewicz-Gierałt \\ Department of Plant Ecology, Institute of Botany, Jagiellonian University, Lubicz 46, 31-512 Kraków, Poland \\ e-mail: kinga.kostrakiewicz@uj.edu.pl
}

Received: 25.04.2013

\begin{abstract}
The present investigations were carried out in the years 2010-2012 in Kraków-Opatkowice (Southern Poland). The observations were conducted in patches of abandoned Molinietum caeruleae meadows with different dominant species. Patch LM was dominated by low meadow species, forming small procumbent shoots and delicate belowground organs; patch TM was occupied by tall-growing taxa creating large tussocks or robust rhizomes; patch $\mathrm{SH}$ was overgrown by shrubs and trees with wide spreading roots. In all patches, the number of ramet clusters of Dianthus superbus was low and constant during the whole study period. All populations showed signs of advanced senility due to the absence of individuals in pre-reproductive stages and the occurrence of generative ramet clusters only. The total number of aboveground units per ramet cluster declined, while the leaf length, height of vegetative and generative stems as well as the size of inflorescences and flowers increased from patch LM to patch TM to patch SH. The presented results provide valuable data concerning the state of ramet clusters studied and their prospects for survival in inhabited sites.
\end{abstract}

Key words: Dianthus superbus L., abundance, cluster of ramets, endangered species, meadow community, population structure

\section{INTRODUCTION}

Large pink Dianthus superbus L. (Caryophyllaceae) is a loosely tufted perennial, clonal forb with a strong primary root and an ascending or creeping rhizome. The vegetative stems are topped with oblong leaves, while generative shoots bear a solitary flower or several flowers grouped in inflorescences. Typical inflorescences have one primary flower, secondary flowers on each side of the central axis, and tertiary flowers on each side of the lateral axis. The flowers are composed of five free, deeply cut fringed petals forming a functional tube enclosed by the tubular calyx. The flowers, producing large amounts of nectar and scent [1], are pollinated exclusively by migratory crepuscular and nocturnal hawkmoths [2]. The aforementioned is listed as a species of the Euro-Siberian subelement, widely but patchily distributed in western, central and eastern Europe as well as in northern Asia [3]. The populations of Large pink occur in moor-grass meadows, peatlands and edges of forests [4]. Dianthus superbus is a threatened species in entire Europe. It is considered as critically endangered (CR) in the Czech Republic [5,6], endangered (EN) in Latvia and Lithuania [7], vulnerable (VU) in Sweden [7] and Poland [8], near threatened (NT) in Hungary [9], and rare $(\mathrm{R})$ in Denmark [7]. In Poland it is locally red-listed as endangered (EN) in South Podlasie Lowland [10] and Gdańsk Pomerania [11] as well as vulnerable (VU) in Opole province [12] and the Carpathians [13]. Taking into account the advanced processes of extinction of numerous populations and the scarcity of data on variation in the features of populations, it should be pointed out that further demographic investigations are still strongly needed. Such observations provide very valuable data about the state of the population and its prospects for survival at occupied sites as well as they might be the basis for successful conservation programs. Considering the present state of knowledge, investigations were conducted on the abundance and structure of populations of Dianthus superbus inhabiting patches of Molinietum caeruleae with different habitat conditions.

\section{STUDY AREA}

The study was carried out in Opatkowice district (N 49 ${ }^{\circ} 59^{\prime} 45.42^{\prime}$ ', E 19 $9^{\circ} 54^{\prime} 12.08^{\prime \prime}$ ) located on the southern edge of Krakow, south of the Vistula River (southern Poland). The observations were conducted simultaneously in three abandoned Molinietum caeruleae meadows which developed at least $250 \mathrm{~m}$ from 
each other and had different site conditions. Patch LM was dominated by small meadow species with delicate underground organs. The low rosette-forbs and small-tussock grasses intercepted a very low amount of irradiance, contributing to strong insolation of the patch area. Patch TM was occupied by tall-growing taxa forming large, compact tussocks or robust rhizomes. The above-mentioned plants quickly fill the gaps in plant canopy, shadowing the whole plot. Patch SH was overgrown by bushes and surrounded by groups of densely grown trees with wide spreading roots, eliminating less competitive species. The compact canopy of leaves strongly decreased the amount of solar radiation reaching the ground surface. The detailed descriptions of the character of vegetation in the study patches are given in Table 1.

Table 1

The habitat characteristics of the patches dominated by small meadow species (patch LM), occupied by tall-growing taxa (patch TM) and partially overgrown by shrubs and trees (patch $\mathrm{SH}$ )

\begin{tabular}{cccc}
\hline Patch abbreviations & Patch LM & Patch TM & Patch SH \\
\hline Patch area $\left(\mathrm{m}^{2}\right)$ & $1400 \mathrm{~m}^{2}$ & $1300 \mathrm{~m}^{2}$ & $1450 \mathrm{~m}^{2}$ \\
\hline Number of species per patch & 58 & 42 & 34 \\
\hline $\begin{array}{c}\text { Dominants in plant canopy } \\
\text { (species with cover } \\
\text { exceeding 20\%) }\end{array}$ & $\begin{array}{c}\text { Lotus corniculatus } \\
\text { Lychnis flos-cucculi } \\
\text { Briza media }\end{array}$ & $\begin{array}{c}\text { Molinia caerulaea } \\
\text { Deschampsia caespitosa }\end{array}$ & $\begin{array}{c}\text { Salix repens ssp. } \\
\text { rosmarinifolia }\end{array}$ \\
\hline $\begin{array}{c}\text { Subdominants in plant canopy } \\
\text { (species with cover } \\
\text { ranging 5-20\%) }\end{array}$ & $\begin{array}{c}\text { Succisa pratensis } \\
\text { Betonica officinalis }\end{array}$ & Phragmites australis & $\begin{array}{c}\text { S. aurita } \\
\text { S. cinerea } \\
\text { Crataegus sp. }\end{array}$ \\
\hline Average vegetation height (cm)* & 44.8 & 73.2 & 128.3 \\
\hline The average vegetation height was calculated on the basis of 50 measurements of randomly chosen stems of different species.
\end{tabular}

* The average vegetation height was calculated on the basis of 50 measurements of randomly chosen stems of different species.

\section{MATERIALS AND METHODS}

The field trial was carried out in the years 2010 2012. Each year the abundance and developmental structure of populations were investigated. Subsequently, the ramet cluster (defined as an aggregation of generative and vegetative stems formed in the course of vegetative propagation of a genet) and the single ramet (understood as a vegetative or generative stem) were adopted as basic demographic units for examination of the size structure. The size structure of ramet clusters is based on the total number of ramets.

The size structure of vegetative stems is based on:

- height (the distance from the ground level to the top);

- the length of the longest leaf.

The size structure of generative stems is based on:

- height (the distance from the ground level to the base of the calyx of the primary flower);

- inflorescence length (measured along the central axis from the base of the lowest lateral axis to the reflex of petals of the primary flower);

- length of the longest corolla tube (measured from the base of the tube to the point of reflex of the petals).

Chi-square statistics were applied to check whether there were significant differences among populations in their structure of size.

\section{RESULTS}

Regardless of habitat conditions, the abundance of Dianthus superbus populations was rather similar. During the whole study period, 11 ramet clusters were found in patch LM, 18 ramet clusters were noted in patch TM, and 12 ramet clusters were observed in patch SH. In all patches, seedlings and juvenile individuals were not found, only the generative ramet clusters were present. The ramet clusters occurring in the whole study area consisted of vegetative and generative stems and the number of above-ground units declined from patch LM to patch TM to patch SH (Fig 1). The vegetative stems found in patch LM measured from $5.0 \mathrm{~cm}$ to $31.0 \mathrm{~cm}$, in patch TM they reached from $4.0 \mathrm{~cm}$ to $46.0 \mathrm{~cm}$, while in site SH they were from $7.0 \mathrm{~cm}$ to $33.0 \mathrm{~cm}$ (Fig. 2). The length of the longest leaf in site LM reached from $3.0 \mathrm{~cm}$ to $7.8 \mathrm{~cm}$, whereas in the other plots it ranged from $3.0 \mathrm{~cm}$ to $8.6 \mathrm{~cm}$ (Fig. 3). The generative stems in LM patch measured from $19.0 \mathrm{~cm}$ to $78.0 \mathrm{~cm}$, in site TM they reached from $21.0 \mathrm{~cm}$ to $96.0 \mathrm{~cm}$, while in site $\mathrm{SH}$ they were from $13.0 \mathrm{~cm}$ to $93.0 \mathrm{~cm}$ (Fig. 4). The inflorescences observed in site LM reached from $5.0 \mathrm{~cm}$ to $28.0 \mathrm{~cm}$, in patch TM they ranged from $4.0 \mathrm{~cm}$ to $30.0 \mathrm{~cm}$, while in site $\mathrm{SH}$ they measured from $3.0 \mathrm{~cm}$ to $29.0 \mathrm{~cm}$ (Fig. 5). Although the length of the longest corolla tube in all patches ranged from $1.0 \mathrm{~cm}$ to $3.0 \mathrm{~cm}$, the average values decreased gradually from LM patch to site TM to site SH (Fig. 6). 

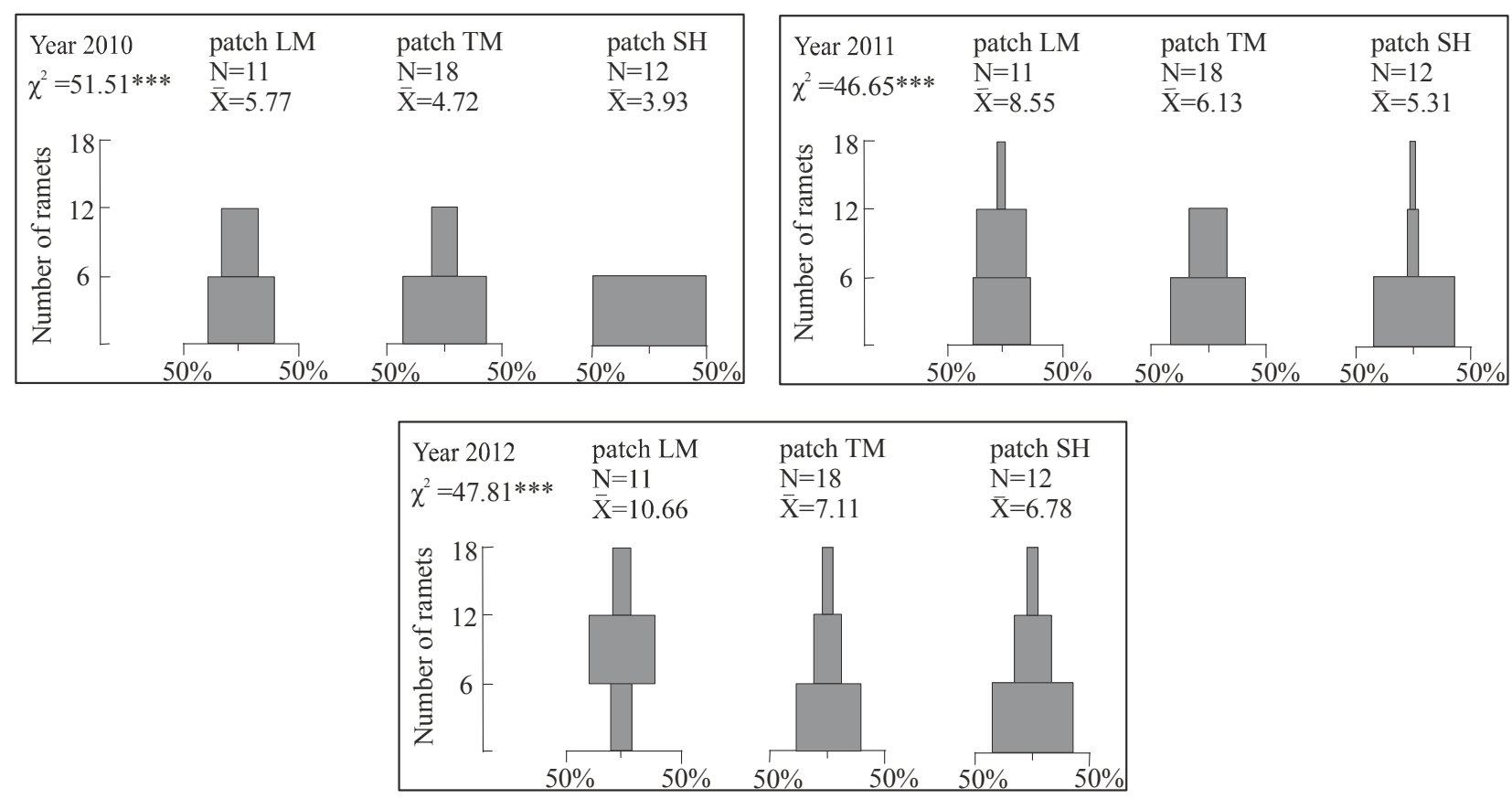

Fig. 1. The size structure of ramet clusters of Dianthus superbus occurring in patches dominated by small meadow species (patch LM), occupied by tall-growing taxa (patch TM) and partially overgrown by shrubs and trees (patch SH) in the period 2010-2012 on the basis of the total number of ramets. Asterisks mean that there are significant differences among populations in each year by the $\chi^{2}$ test at the 0.001 level.
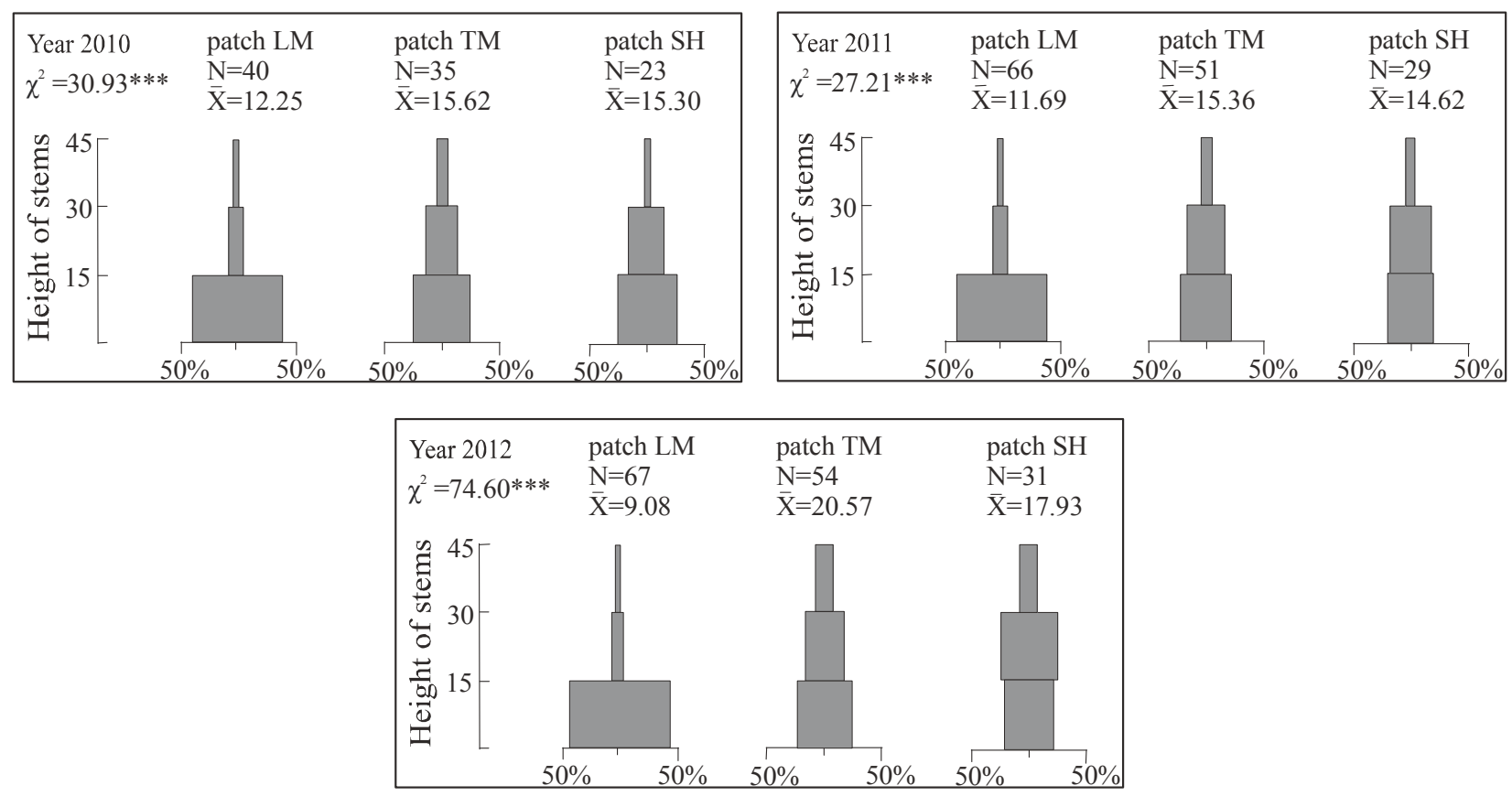

Fig. 2. The structure of the size of vegetative stems of Dianthus superbus occurring in patches dominated by small meadow species (patch LM), occupied by tall-growing taxa (patch TM) and partially overgrown by shrubs and trees (patch SH) in the period 2010-2012 on the basis of height $(\mathrm{cm})$. Asterisks mean that there are significant differences among populations in each year by the $\chi^{2}$ test at the 0.001 level. 


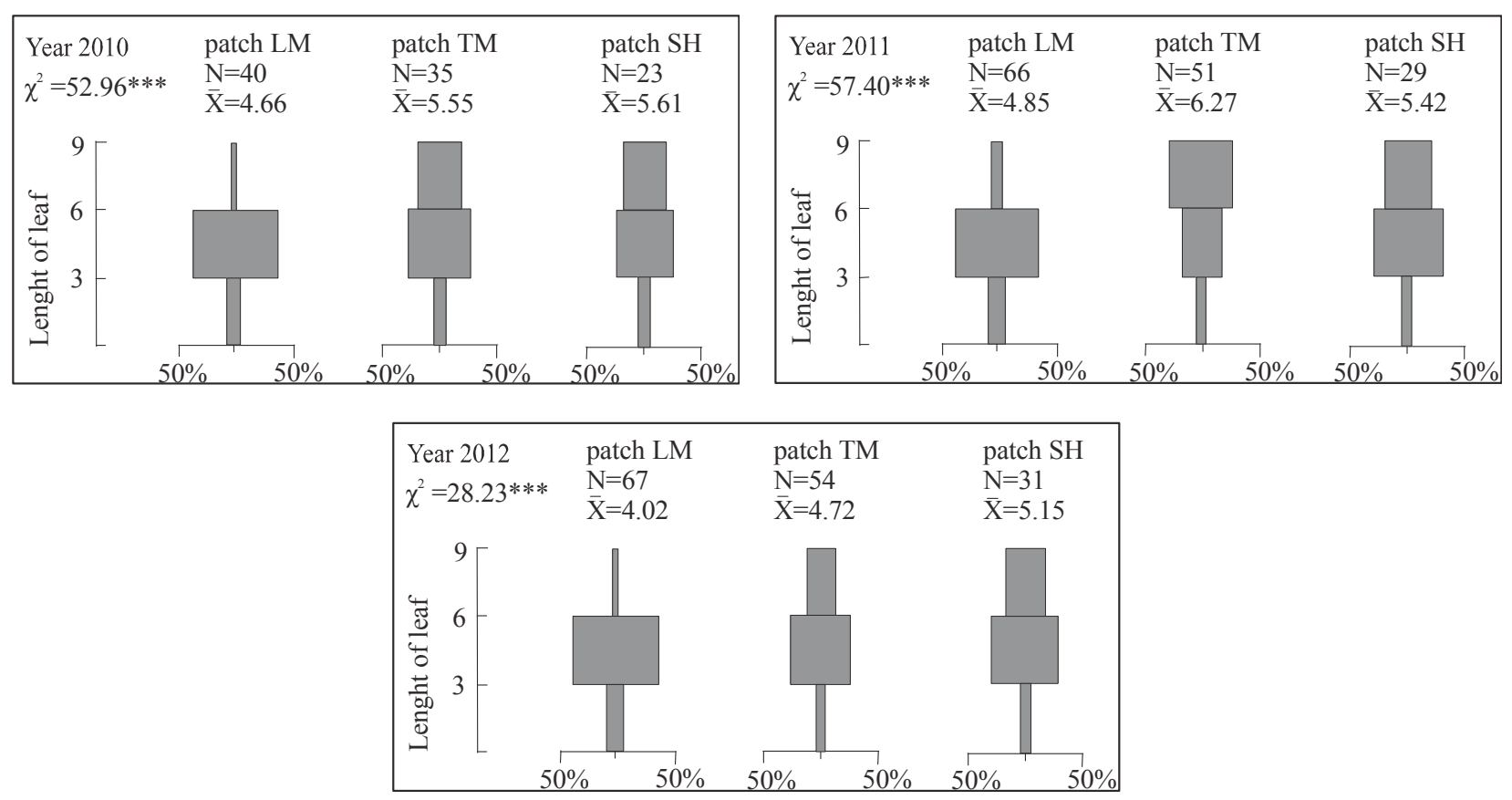

Fig. 3. The structure of the size of vegetative stems of Dianthus superbus occurring in patches dominated by small meadow species (patch LM), occupied by tall-growing taxa (patch TM) and partially overgrown by shrubs and trees (patch SH) in the period 2010-2012 on the basis of length of the longest leaf $(\mathrm{cm})$. Asterisks mean that there are significant differences among populations in each year by the $\chi^{2}$ test at the 0.001 level.
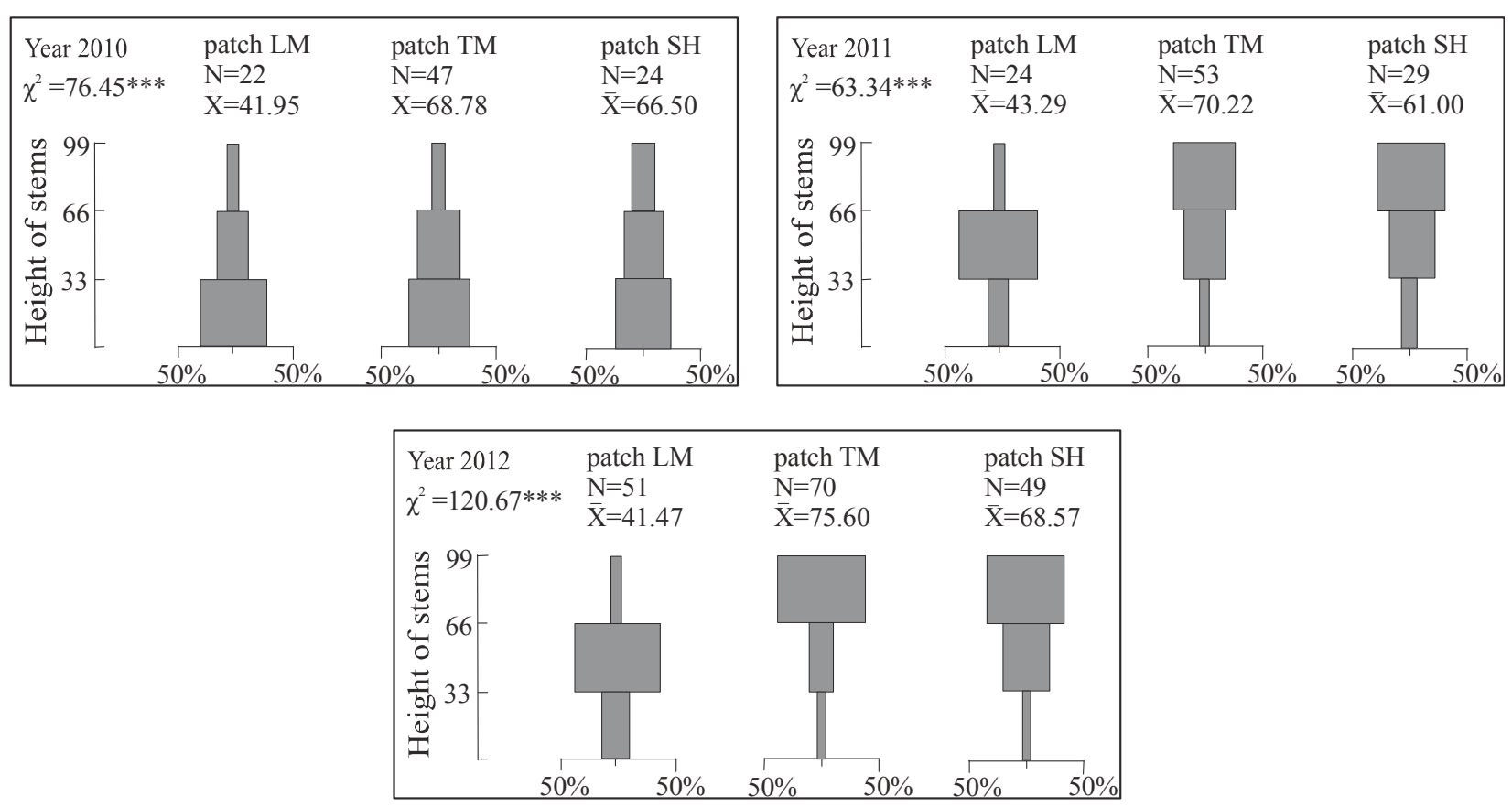

Fig. 4. The structure of the size of generative stems of Dianthus superbus occurring in patches dominated by small meadow species (patch LM), occupied by tall-growing taxa (patch TM) and partially overgrown by shrubs and trees (patch SH) in the period 2010-2012 on the basis of height $(\mathrm{cm})$. Asterisks mean that there are significant differences among populations in each year by the $\chi^{2}$ test at the 0.001 level. 

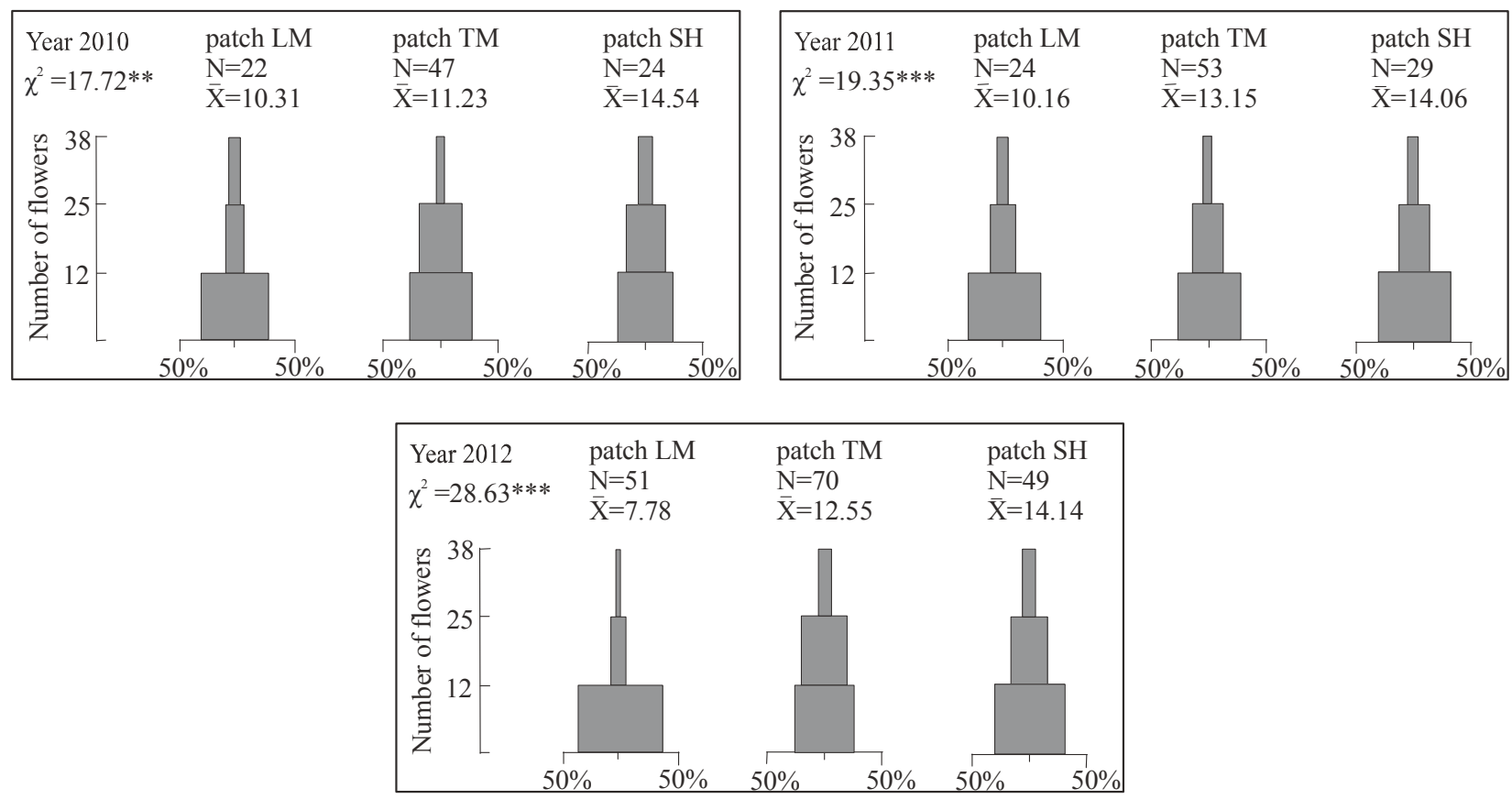

Fig. 5. The structure of the size of generative stems of Dianthus superbus occurring in patches dominated by small meadow species (patch LM), occupied by tall-growing taxa (patch TM) and partially overgrown by shrubs and trees (patch SH) in the period 2010-2012 on the basis of length of inflorescence $(\mathrm{cm})$. Asterisks mean that there are significant differences among populations in each year by the $\chi^{2}$ test at the 0.01 level (**) or at the 0.001 level (***).
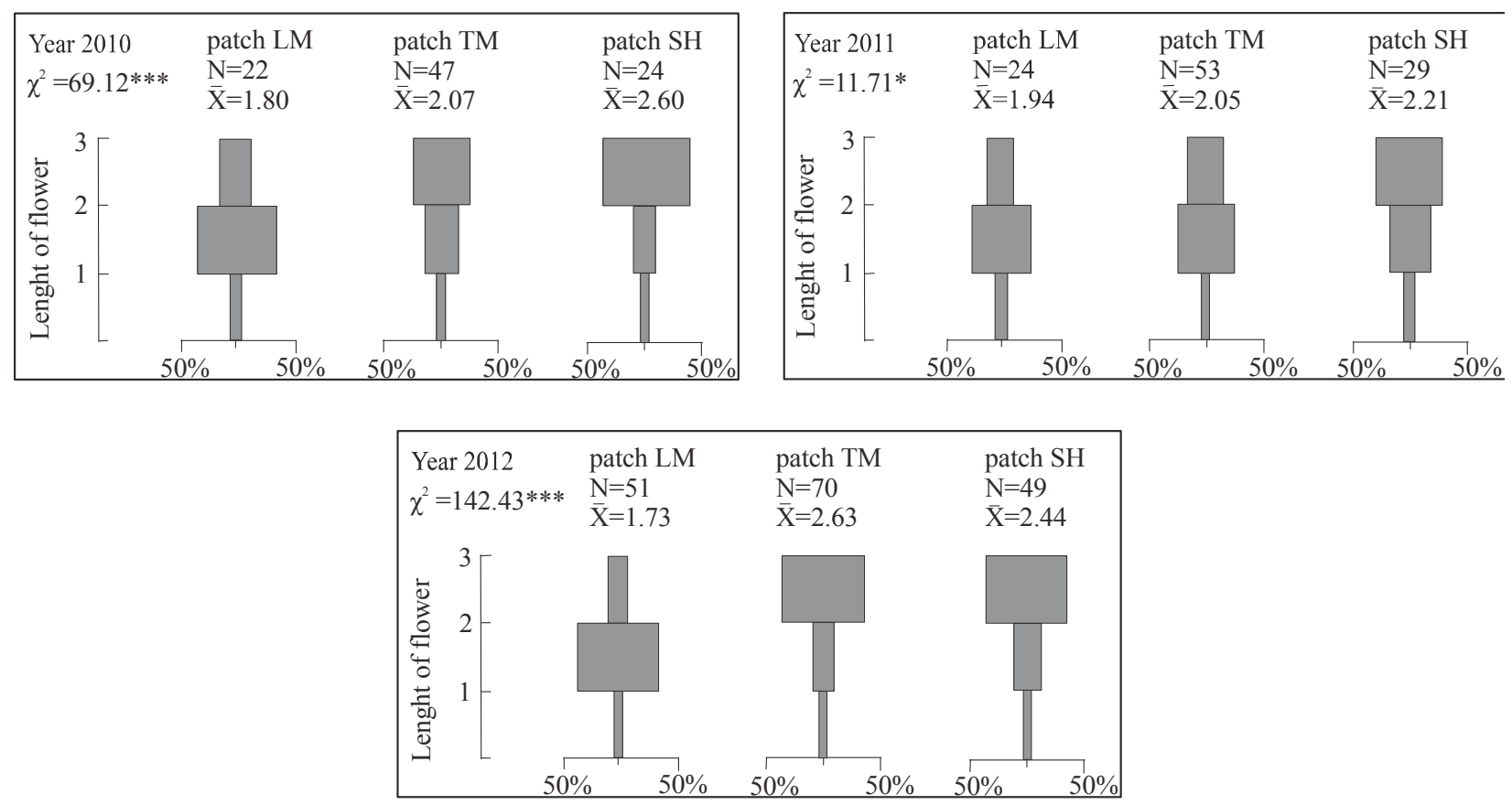

Fig. 6. The structure of the size of generative stems of Dianthus superbus occurring in patches dominated by small meadow species (patch LM), occupied by tall-growing taxa (patch TM) and partially overgrown by shrubs and trees (patch SH) in the period 2010-2012 on the basis of length of the longest flower $(\mathrm{cm})$. Asterisks mean that there are significant differences among populations in each year by the $\chi^{2}$ test at the 0.05 level (*) or at the 0.001 level (***). 


\section{DISCUSSION}

The constant abundance and advanced signs of senility might be caused by a lack of safe sites for recruitment and establishment of seedlings. At the same time, it should be argued that both gaps in continuous plant cover and litter as well as disintegrating large-tussock grasses $[14,15]$ may perform the role of microhabitats suitable for the emergence of generative offsprings in Molinietum caeruleae meadows.

The present observations showing that the number of aboveground units declined from patch LM to patch TM to patch SH support the studies carried out in populations of other species occurring in abandoned wet and humid meadows such as Filipendula ulmaria [16], Iris pseudacorus [17], and I. sibirica [18]. The aforementioned authors claim that neighbouring plants, achieving great dimensions and creating robust underground organs, contribute to the successive depletion of space necessary for vegetative multiplication of ramets.

The present investigations showed that the height of vegetative stems and the length of the longest leaf of Dianthus superbus were larger at the site dominated by low meadow species than in the plots dominated by tall-growing taxa and the place overgrown by shrubs and trees. Under crowding conditions and in the vicinity of tall-growing plants, the increase in height of vegetative organs might be advantageous because it allows plants to outperform neighbours and contributes to more effective light interception. A similar phenomenon was observed in populations of Trollius europaeus [19] and Iris sibirica [20]. Moreover, the obtained results are consistent with a wide array of observations carried out on vegetative individuals of various species, documenting an increase of allocation in leaves and stems under crowding conditions [21].

The present study demonstrating the increase in length of generative stems with the augmentation of the shading level corresponds with studies conducted in populations of Iris sibirica [20] and Gentiana pneumonanthe [22]. Such a phenomenon may contribute to better visibility of inflorescences and flowers for pollinators. Also, the recorded increase in length of inflorescence of Dianthus superbus taking place under unfavourable crowding conditions may enhance the attractiveness of plants to pollinators and maximize mating opportunities. A similar tendency was recorded in numerous studies reviewed by $\mathrm{H}$ a r d e $\mathrm{r}$ et al. [23]. At the same time, it should be added that the pollinator preference for larger inflorescences as well as inflorescences positioned at a greater height was observed during experimental manipulations carried out in individuals of Silene virginica [24], a species closely related to Dianthus.
The observed gradual increase in the dimensions of Dianthus superbus flowers in successive patches may be associated with the growing amount of nectar and more frequent pollinator visits. Silene virginica showed a positive correlation between the dimensions of flowers, quantity and quality of nectar as well as the frequency of pollinator visits [25]. On the other hand, the observations of pollination ecology of Silene latifolia [26] and Silene acutifolia [27] demonstrated that the size of flowers has no effect on insect visitation.

\section{CONCLUSIONS}

1. The constant low abundance and signs of advanced senility observed in all populations of Dianthus superbus might be due to a lack of safe sites suitable to recruitment and establishment of seedlings.

2. The number of aboveground units per ramet cluster diminishes, while the length of leaves, the height of vegetative and generative stems as well as the size of leaves, inflorescences and flowers increase with the augmentation of dimensions of neighbouring plants.

3. The population inhabiting Patch LM has the highest chances for survival because of intense vegetative multiplication of ramets, compensating the low abundance and small investment in the size of stems, inflorescences, flowers and leaves. The population occurring in Patch TM is characterized by an average state being a result of greater abundance and considerable allocation of biomass in vegetative and generative structures. The highest risk of extinction, due the scarce number of ramet clusters consisting of a small number of aboveground units, is related to the population established in Patch SH.

\section{Acknowledgements}

I would like to thank the anonymous reviewers for their valuable suggestions which enabled an improvement of the manuscript.

\section{REFERENCES}

1. Jürgens A, Witt T, Gottsberger G. Flower scent composition in Dianthus and Saponaria species (Caryophyllaceae) and its relevance for pollination biology and taxonomy. Bioch. Syst. Ecol. 2003; 31: 345-357. http://dx.doi. org/10.1016/S0305-1978(02)00173-4

2. Erhard A. Pollination of Dianthus superbus L. Flora, 1991; 185(2): 99-106.

3. Meusel H, Jäger E, Weinert E. Vergleichende Chorologie der Zentraleuropäischen Flora. Bd. I. Jena: Gustav Fisher; 1965. (in German) 
4. Matuszkiew ic z W. Przewodnik do oznaczania zbiorowisk roślinnych Polski. Warszawa: Wydawnictwo Naukowe PWN; 2012. (in Polish)

5. Holub J., Procházka F. Red list of the flora of the Czech Republic (state in the year 2000). Preslia, Praha. 2000; 72: 187-230.

6. Grulich V. Red list of vascular plants of the Czech Republik Preslia, Praha. 2012; 84: 631-645.

7. Ingelög T., Andersson R., Tjenberg M. Red Data Book of The Baltic Region. Part 1 Lists of threatened vascular plants and vertebrates. Uppsala: Swedish Threatened Species Unit, Riga: Institute of Biology; 1993.

8. Zarzycki K., Szeląg Z. Red List of Vascular Plants in Poland In: Mirek Z, Zarzycki K, Wojewoda W, Szeląg Z., editors. Red List of Plants and Fungi in Poland. Kraków: W. Szafer Polish Academy of Sciences; 2006.

9. K i rály G. editor. Red list of the vascular flora of Hungary. Sopron: Saját kiadás; 2007.

10. Głowacki Z., Falkowski M., Krechowski J., Marciniuk J., Marciniuk P., NowickaFalkowska K. et al. The red list of vascular plant of the Południowopodlaska Lowland. Chrońmy Przyr. Ojcz. 2003; 59(2): 5-41.

11. Olszewski T.S., Markowski R. Addenda to the red list of vascular plants of Gdańsk Pomerania 2. [In:] T.S. Olszewski, R. Afranowicz, K. Bociąg (eds) Contemporary trends of botanical research - on Professor Hanna Piotrowska $80^{\text {th }}$ birthday anniversary. Acta Bot. Cassub. 2006; 6: 163-172.

12. Nowak A., Spałek K. Goździk pyszny Dianthus superbus L.s.s. [In:] A. Nowak, K. Spałek (eds) Czerwona Księga Roślin Województwa Opolskiego. Opole: OTPN; 2002. (in Polish)

13. Bartoszek W., Szewczyk M., Wróbel D., Mróz K., Oklejewicz K. Goździk pyszny Dianthus superbus L. [In:] Z. Mirek, H. Piękoś-Mirkowa (eds) Czerwona Księga Karpat Polskich. Kraków: W. Szafer Polish Academy of Sciances; 2008. (in Polish)

14. Kostrakiewicz K. The effect of gaps on seedlings recruitment of threatened species in Molinietum caeruleae W. Koch 1926 patches. Chrońmy Przyr. Ojcz. 2010; 66(3): 184-189.

15. Kostrakiewicz K. Colonization of Deschampsia cespitosa L. tussocks by threatened species of blue moor-grass meadows Molinietum caeruleae W.Koch 1926. Chrońmy Przyr. Ojcz. 2011; 67(6): 527-533.

16. Falińs ka K. Genet disintegration in Filipendula ulmaria: consequences for population dynamics and vegetation succession. J. Ecol. 1995; 83:9-21. http://dx.doi.org/ $10.2307 / 2261146$

17. Falińska K. Demography of Iris pseudacorus L. populations in abandoned meadows. Ekol. Pol. 1986; 34(4): 583-613.

18. Kostrakiewicz K. The effect of dominant species on numbers and age structure of Iris sibirica L. population on blue moor-grass meadow in southern Poland. Acta Bot. Soc. Pol. 2007; 76(2): 165-173.
19. Kostrakiewicz K. The influence of shadow created by adjacent plants on phenotypic plasticity of endangered species Trollius europaeus L. (Ranunculaceae). Pol. J. Ecol. 2009; 57(4): 625-634.

20. Kostrakiewicz K. Population structure of a clonal endangered plant species Iris sibirica $\mathrm{L}$. in different habitat conditions. Pol. J. Ecol. 2008; 56(4): 581-592.

21. Poorter H., Niklas K.J., Reich P.B., Oleksyn J., Poot P., Mommer L. Biomass allocation to leaves, stems and roots: meta-analyses of interspecific variation and environmental control. New Phytologist. 2011; 193(1): 30-50. http://dx.doi.org/10.1111/j.1469-8137.2011. 03952.x

22. Kostrakiewicz-Gierałt K. The effect of vegetation character on abundance and structure of subpopulations of rare herb Gentiana pneumonanthe L. Pol. J. Ecol. 2013; 61(1): 35-46.

23. Harder L.D., Jordan C.Y., Gross W.E., Routley M.B. Beyond floricentrism: The pollination function of inflorescences. Plant Spec. Biol. 2004; 19: 137148.

24. Dudash M.R., Hassler C., Stevens P.M., Fenster Ch.B. Experimental floral and inflorescence trait manipulations affect pollinator preference and function in a hummingbird-pollinated plant. Am. J. Bot. 2011; 98(2): 275-282. http://dx.doi.org/10.3732/ajb.1000350

25. Fenster Ch.B., Cheely G., Dudash M.R., Reynolds R. J. Nectar reward and advertisement in 24. hummingbird-pollinated Silene virginica (Caryophyllaceae). Am. J. Bot. 2006; 93(12): 1800-1807. http://dx.doi.org/10. 3732/ajb.93.12.1800

26. Wright J.W, Meagher T.R. Selection on floral characters in natural Spanish populations of Silene latifolia. J. Evol. Biol. 2004; 17: 382-395. http://dx.doi.org/ 10.1046/j.1420-9101.2003.00671.x

27. Buide M.L. Pollination ecology of Silene acutifolia (Caryophyllaceae): floral traits variation and pollinator attraction. Ann. Bot. 2005; 97(2): 289-297. http://dx.doi.org/ 10.1093/aob/mcj032

\section{Struktura wielkości ramet Dianthus superbus L. w mozaikowej roślinności łąkowej}

\section{Streszczenie}

Badania liczebności i struktury wielkości ramet ginącego, klonalnego gatunku Dianthus superbus prowadzono w latach 2010-2012 w płatach nieużytkowanych łąk trzęślicowych Molinietum caeruleae, cechujących się stopniowym wzrostem wysokości runi. Płat LM cechował się znacznym udziałem roślin łąkowych tworzących niskie, płożące pędy i delikatne organy podziemne, płat TM wyróżniał się znacznym udziałem wysokich gatunków kępowych lub kłączowych, natomiast płat SH był częściowo zarośnięty przez krzewy 
i drzewa, tworzące duże i rozgałęzione systemy korzeniowe.

Wszystkie badane populacje Dianthus superbus charakteryzowały się niską liczebnością i oznakami starzenia wynikającymi z braku bezpiecznych miejsc do rekrutacji siewek i rozwoju osobników juwenilnych. Odnotowany w kolejnych płatach stopniowy spadek liczby ramet w skupieniach mógł być spowodowany brakiem wolnych miejsc niezbędnych do klonalnego pomnażania jednostek nadziemnych. Wzrost długości pędów wegetatywnych oraz liści wraz ze zwiększaniem się wysokości pokrywy roślinnej umożliwia efektywniejsze pochłanianie światła słonecznego w sąsiedztwie wysokich roślin. Z kolei, zwiększenie wysokości pędów generatywnych oraz długości kwiatostanów i kwiatów w otoczeniu wysokich sąsiadów może umożliwiać skuteczne zapylanie.

Podsumowując, stwierdzić można, że najlepsza kondycja cechuje skupienia ramet Dianthus superbus bytujące w płacie LM, gdzie niewielka wysokość pędów oraz mała długość liści, kwiatostanów i kwiatów jest rekompensowana przez intensywne pomnażanie ramet. Pomimo słabego wzrostu klonalnego, skupienia ramet występujące w płacie TM charakteryzują się zadawalającym stanem ze względu na znaczną alokację biomasy w pędy wegetatywne i generatywne. Największe ryzyko wyginięcia wynikające z nieznacznej liczby pędów cechuje skupienia ramet usytuowane w płacie SH.

Handling Editor: Elżbieta Weryszko-Chmielewska

This is an Open Access digital version of the article distributed under the terms of the Creative Commons Attribution 3.0 License (creativecommons.org/licenses/by/3.0/), which permits redistribution, commercial and non-commercial, provided that the article is properly cited.

CThe Author(s) 2013 Published by Polish Botanical Society 